\title{
Demography of loggerhead turtles Caretta caretta in the southeastern Pacific Ocean: fisheries-based observations and implications for management
}

\author{
Joanna Alfaro Shigueto ${ }^{1,2, *}$, Jeffrey C. Mangel ${ }^{1,2}$, Jeffrey A. Seminoff ${ }^{3}$, \\ Peter H. Dutton ${ }^{3}$ \\ ${ }^{1}$ Pro Delphinus, Octavio Bernal 572-5, Lima 11, Peru \\ ${ }^{2}$ University of Exeter, Cornwall Campus, Center for Ecology and Conservation, Penryn, Cornwall TR10 9EZ, UK \\ ${ }^{3}$ NOAA-National Marine Fisheries Service, Southwest Fisheries Science Center, 8604 La Jolla Shores Drive, \\ La Jolla, California 92037, USA
}

\begin{abstract}
Since 2000 we have used artisanal fishing operations as an opportunistic platform for inwater studies of marine megafauna, including sea turtles. We present data on loggerhead turtles Caretta caretta incidentally captured by artisanal longline and gillnet fisheries activities operating from 7 ports along the coast of Peru. Data on location, body size and apparent maturity class of loggerheads were gathered. A total of 323 loggerhead turtle captures were recorded between latitudes 13 and $22^{\circ} \mathrm{S}$ in waters from 46.5 to $637.1 \mathrm{~km}$ off shore. Curved carapace length (CCL) ranged from 35.9 to $86.3 \mathrm{~cm}$ (mean $\pm \mathrm{SD}=57.2 \pm 9.18 \mathrm{~cm}, \mathrm{n}=307$ ), which equated to a predominance of juvenile turtles. The substantial fishing effort of the fisheries sampled (63 083 gillnet and 11316 longline trips $\mathrm{yr}^{-1}$ ) underscores the importance of mitigating fisheries impacts on loggerheads in the southeastern Pacific. We recommend that regional research and conservation work quantitatively document and, where possible, reduce impacts to loggerheads in the southeastern Pacific foraging area.
\end{abstract}

KEY WORDS: Bycatch · Artisanal fisheries $\cdot$ Sea turtles $\cdot$ Loggerheads $\cdot$ Southeastern Pacific $\cdot$ Peru

\section{INTRODUCTION}

The loggerhead turtle Caretta caretta is listed globally as endangered on the World Conservation Union (IUCN) Red List (IUCN 2007). In the Pacific, the primary nesting populations are located in Japan and eastern Australia (Uchida \& Nishiwaki 1992, Bowen 1995, Limpus \& Limpus 2003a), and annual nesting abundance has declined in recent decades in both regions (Limpus \& Reimer 1994, Chaloupka \& Limpus 2001, Kamezaki et al. 2003). These reductions are largely the result of impacts at nesting beaches (i.e. egg predation by foxes, raccoons, and weasels at nesting sites), but also due to impacts from interactions with marine fisheries gear (Wetherall et al. 1993, Poiner \& Harris 1996, Lewison et al. 2004). Until re- cently, the issue of fisheries bycatch of sea turtles has been largely focused on the high-seas industrial fisheries (Wetherall et al. 1993, Poiner \& Harris 1996, Lewison et al. 2004, Casale et al. 2007). Bycatch in artisanal fisheries has now been recognized as a major threat (Gallo et al. 2006, Lum 2006, Pupo et al. 2006, Alfaro Shigueto et al. 2007, Bal et al. 2007, Dossa et al. 2007, Lewison \& Crowder 2007, Peckham et al. 2007, Dutton \& Squires 2008). Nevertheless, small-scale artisanal fisheries are distributed throughout the world in areas that overlap important sea turtle habitats, and are therefore a significant challenge for sea turtle conservation efforts (Koch et al. 2006, Read 2007, Dutton \& Squires 2008).

In the Pacific Ocean, the bulk of research on migratory behavior and habitat use has been conducted in 
the North Pacific (Polovina et al. 2000, 2004, 2006). TransPacific linkages have been demonstrated, connecting loggerhead activity in and around Baja California, Mexico, to breeding areas in Japan (Bowen 1995, Resendiz et al. 1998, Nichols et al. 2000, Seminoff et al. 2004, Koch et al. 2006, Peckham et al. 2007). Less is known about the loggerheads in the South Pacific, although the recent discovery of loggerheads off the coast of South America suggests life-history patterns that are similar to the North Pacific, with linkages between the southern nesting stocks in Australia and distant foraging grounds in the eastern tropical Pacific (Donoso et al. 2000, Kelez et al. 2003, Alfaro Shigueto et al. 2004). Ongoing genetic studies indicate that the loggerhead turtles off Peru and Chile originate from southern hemisphere nesting stocks in eastern Australia (Donoso et al. 2000, Alfaro Shigueto et al. 2004) and perhaps New Caledonia (P. H. Dutton unpubl. data).

In Peru, loggerhead turtles are known locally as 'amarilla' (yellow) or 'cabezona' (big head) turtles, and are commonly captured in artisanal fisheries off the southern coast (Alfaro Shigueto et al. 2004). Their meat is sometimes used for human consumption either on board, at fishing communities, or commercialized in domestic markets (Alfaro Shigueto et al. 2004). However, few demographic data are available, due largely to the pelagic nature of their distribution and the difficulty of accessing these areas for scientific studies.

There is scant information on the stock's spatial distribution, the size classes of the pelagic stages, and the foraging ecology of loggerheads in the South Pacific. Fisheries can provide a useful and practical platform for gathering information on marine species, such as sea turtles, that spend most of their lives at sea. By placing onboard observers on artisanal fishing vessels from several ports along the Peruvian coast, we describe the occurrence and distribution of loggerhead turtles in coastal Peruvian waters and use this information to define the size classes of loggerhead turtles captured by artisanal vessels off the coast of Peru and, ultimately, to provide information for sea turtle conservation and management decision making.

\section{MATERIALS AND METHODS}

Study area. The southeastern tropical Pacific contains highly productive waters, due largely to the wind-driven upwelling of the cold, nutrient-rich waters of the Peru-Humboldt Current System along the west coast of South America (Fiedler et al. 1991, Bertrand et al. 2004, Hatziolos \& de Haan 2006). The normal seasurface temperature (SST) typically ranges from 15 to $17^{\circ} \mathrm{C}$ in the austral winter (June to September) and 21 to $26^{\circ} \mathrm{C}$ in the austral summer (December to March).
Higher temperatures $\left(>26^{\circ} \mathrm{C}\right)$ are restricted to northern areas near the tropics (Bertrand et al. 2004). Chlorophyll a (chl a) ranges from 39 to $47 \mathrm{mg} \mathrm{C} \mathrm{mg}^{-1} \mathrm{chl} \mathrm{a} \mathrm{d}^{-1}$ (Fiedler et al. 1991). The productivity of Peruvian waters is also shown by the large number of fishing ports (106 landing sites) (Escudero 1997) distributed along the $3000 \mathrm{~km}$ of Peruvian coastline, with approximately 9667 artisanal fishing vessels (Estrella 2007).

Fisheries platforms. Artisanal vessels are defined here (and according to Peruvian fisheries regulations) as boats with a maximum of $32.6 \mathrm{~m}^{3}$ of storage capacity, $15 \mathrm{~m}$ in length, and that are principally based upon manual work rather than mechanically operated fishing gear (El Peruano Ministerio de la Producción 2001). Due to their large capacity, these can be considered as small- to medium-scale vessels. There are an estimated 63083 gillnet (Estrella et al. 1999, 2000) and 11316 longline trips annually (IMARPE unpubl. data).

This study was conducted from 11 ports along the coast of Peru (Table 1, Fig. 1). Data were collected from artisanal longline and gillnet vessels between 17 November 2000 and 29 May 2007 through an onboard observer program. Participation of vessels in the program was voluntary. Sampling effort of fishing trips depended on the availability of infrastructural resources (observers, funding), availability of vessels, and weather conditions.

Onboard observers were trained in data and sample collection methods and species identification, including seabirds, sharks, small cetaceans, and sea turtles (Harrison 1983, Jefferson et al. 1993, Onley \& Bartle 1999, Pritchard \& Mortimer 1999, Compagno et al.

Table 1. Caretta caretta. Ports monitored, number of trips observed, fishing method used and the number of loggerheads incidentally caught

\begin{tabular}{|llccc|}
\hline Port & Location & $\begin{array}{c}\text { No. of } \\
\text { trips }\end{array}$ & $\begin{array}{c}\text { Fishing } \\
\text { gear }\end{array}$ & $\begin{array}{c}\text { No. of } \\
\text { loggerheads } \\
\text { caught }\end{array}$ \\
\hline North & & & & \\
Mancora & $04^{\circ} 05^{\prime} \mathrm{S}, 81^{\circ} 04^{\prime} \mathrm{W}$ & 2 & Net & 0 \\
Paita & $05^{\circ} 05^{\prime} \mathrm{S}, 81^{\circ} 06^{\prime} \mathrm{W}$ & 4 & Longline & 0 \\
Constante & $05^{\circ} 35^{\prime} \mathrm{S}, 81^{\circ} 00^{\prime} \mathrm{W}$ & 33 & Net & 0 \\
Salaverry & $08^{\circ} 14^{\prime} \mathrm{S}, 78^{\circ} 59^{\prime} \mathrm{W}$ & 23 & Longline & 3 \\
Chimbote & $09^{\circ} 05^{\prime} \mathrm{S}, 78^{\circ} 36^{\prime} \mathrm{W}$ & 33 & Net & 2 \\
Supe & $10^{\circ} 48^{\prime} \mathrm{S}, 77^{\circ} 45^{\prime} \mathrm{W}$ & 1 & Longline & 2 \\
Center & & & Net & 0 \\
Ancon & $11^{\circ} 46^{\prime} \mathrm{S}, 77^{\circ} 10^{\prime} \mathrm{W}$ & 4 & Longline & 1 \\
Callao & $12^{\circ} 03^{\prime} \mathrm{S}, 77^{\circ} 08^{\prime} \mathrm{W}$ & 19 & Longline & 29 \\
Pucusana & $12^{\circ} 29^{\prime} \mathrm{S}, 76^{\circ} 47^{\prime} \mathrm{W}$ & 15 & Longline & 23 \\
South & & & & \\
Marcona & $15^{\circ} 21^{\prime} \mathrm{S}, 75^{\circ} 10^{\prime} \mathrm{W}$ & 1 & Longline & 0 \\
Ilo & $17^{\circ} 38^{\prime} \mathrm{S}, 71^{\circ} 20^{\prime} \mathrm{W}$ & 170 & Longline & 263 \\
Total & & 328 & & 323 \\
\hline
\end{tabular}




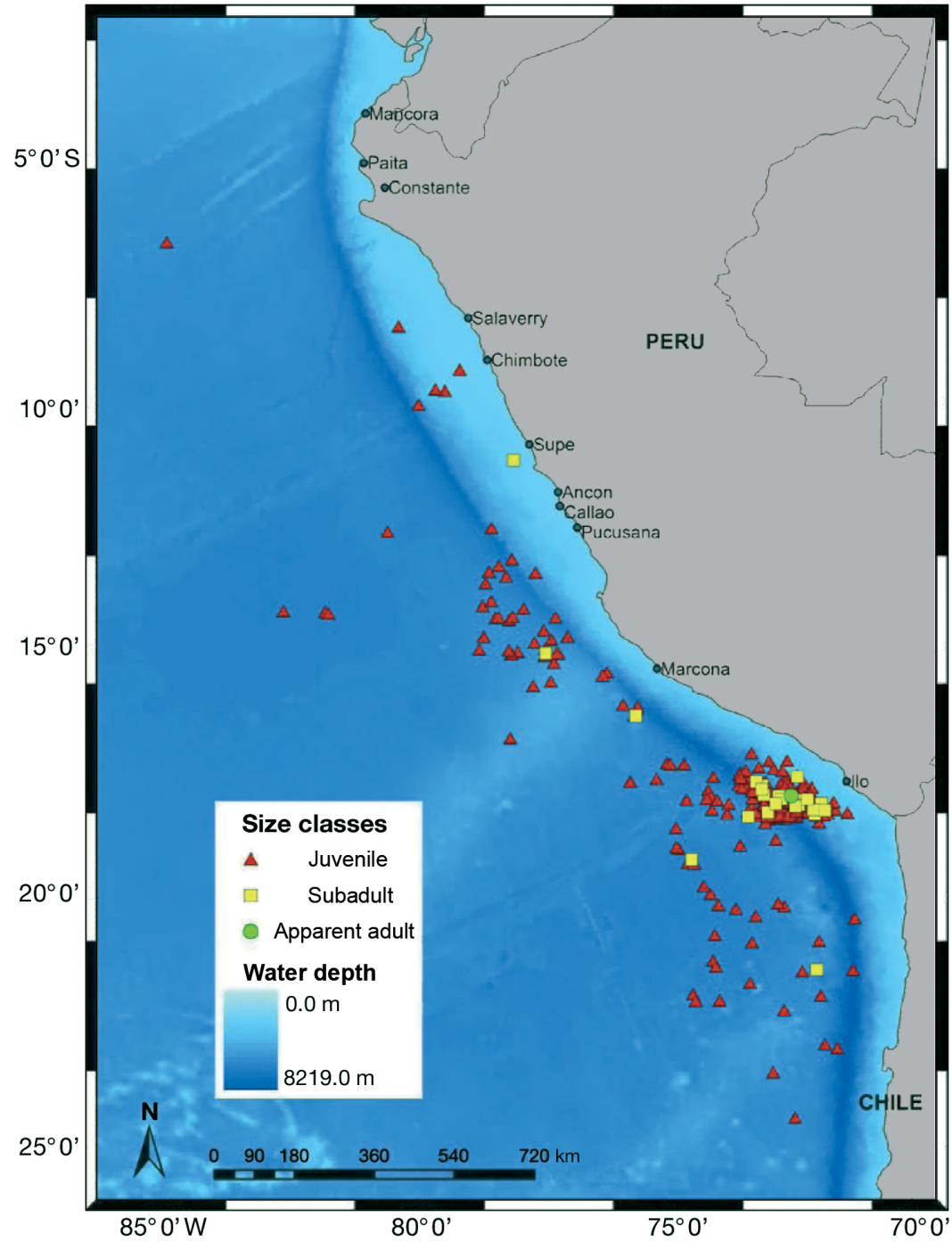

Fig. 1. Caretta caretta. At-sea locations of loggerhead turtles captured off Peru $(\mathrm{n}=299)$. Loggerhead turtles were grouped by curved carapace length size classes: juveniles $(<70 \mathrm{~cm})$, subadult $(70$ to $85 \mathrm{~cm})$ and apparent adults $(>85 \mathrm{~cm})$

2005). For data collection on target and non-target species, observers recorded information on fishing operations, locations of fishing areas, vessel-specific gear used, and the catch and bycatch obtained during the fishing trip. In addition, observers photographed turtles for subsequent confirmation of species identity (see Alfaro Shigueto et al. 2004).

A total of 328 trips (of these 7 were unable to conduct regular fishing operations and thus were excluded) were observed during the study period (Table 1). Fishing trips monitored lasted 1 to $27 \mathrm{~d}$ (mean $\pm \mathrm{SD}=$ $9.68 \pm 0.3 \mathrm{~d}, \mathrm{n}=321$ trips). Trips targeting mahi mahi operated in the austral summer season (December to March), while those targeting sharks were conducted during the remainder of the year (autumn through spring). Observers in Paita, Chimbote, Ancon, Callao, Pucusana, Marcona, and Ilo monitored longline trips. For Mancora, Constante, and Supe, only gillnets were sampled. In the port of Salaverry, we monitored both longlines and gillnets (Table 1, Fig. 1).

Gillnet vessels sampled in our study targeted multiple species, including blue sharks Prionace glauca and shortfin mako sharks Isurus oxyrinchus, and, to a lesser extent, hammerhead sharks Sphyrna zygaena, thresher sharks Alopias vulpinus, smooth-hound sharks Mustelus spp., rays Triakis sp., Myliobatis peruvianus, and $M$. chilensis, mahi mahi Coryphaena hippurus, angelsharks Squatina californica, guitarfishes Rhinobatos planiceps, lobsters Panulirus gracilis, and flounder Paralichthys adspersus, among other coastal species (J. Alfaro Shigueto et al. unpubl. data). Longline vessels targeted mahi mahi and sharks (especially blue and shortfin mako). The areas of operation of these artisanal vessels included oceanic (>200 m) and neritic waters ( $\leq 200 \mathrm{~m}$ ).

Morphometric data and turtle handling. Hooked or entangled turtles were brought on board, measured, photographed, and sampled for other studies not described here (i.e. genetics, stable isotopes). Information collected for each turtle included the location (latitude and longitude) of capture, curved carapace length (CCL; measured from the nuchal notch to posterior-most tip), and carapace curved width $(\mathrm{CCW}$; at the widest part of the shell) (Bolten 1999). Measurements were made using a metric tape $( \pm 0.1 \mathrm{~cm})$. Turtles in good condition were typically released within $1.5 \mathrm{~h}$ of landing. Released turtles were double tagged with Inconel tags (Style 681; National Band and Tag Company) applied to the trailing edge of both front flippers. For injured and comatose turtles, we followed handling and resuscitation techniques described on the NOAA Southeast Fisheries Science Center website for onboard observers (www.sefsc. noaa.gov/seaturtlefisheriesobservers.jsp). Dead turtles were measured and then discarded at sea.

The level of injury of bycatch turtles was classified as 'severely hooked' or 'lightly hooked'. We defined severely hooked as a hook that was compromising the tongue, esophagus, or was swallowed, or when the hook was located in the upper jaw, potentially compro- 
mising brain functions. Turtles classified as lightly hooked were those hooked externally (neck, flippers), or where the hook was located in the sides of the mouth or in the lower jaw.

We inferred maturity status using size thresholds from the literature on the eastern Australia loggerhead population (Limpus \& Limpus 2003b), which is believed to be part of the same genetic stock as loggerheads in the southeastern Pacific (Donoso et al. 2000, Alfaro Shigueto et al. 2004, P. H. Dutton et al. unpubl. data). We acknowledge that there is no knifeedge differentiation for animal size and stage class of maturation, especially since no internal analyses were conducted for the individuals caught during the present study. However, to facilitate comparisons with studies in the western Pacific (Limpus \& Limpus 2003b), we classified loggerheads as juveniles, subadults, and adults, based on CCLs of $<70 \mathrm{~cm}, 70$ to $85 \mathrm{~cm}$, and $>85 \mathrm{~cm}$, respectively (Limpus \& Limpus 2003b).

Mean lengths $( \pm 1$ SD) are given unless otherwise indicated. We used SPSS 15.0 for statistical analyses. Significance was established when $\mathrm{p} \leq 0.05$. Maps were created using MAPTOOL (SEATURTLE.ORG, V. 2002, available at www.seaturtle.org/maptool).

\section{RESULTS}

\section{Loggerhead interactions and spatial distribution}

A total of 323 loggerhead turtles Caretta caretta were examined during this study (Table 1). The majority of turtles (82\%) were captured by vessels operating out of Ilo, and $99 \%$ were captured due to interactions with longline gear (Table 1).

All but 1 loggerhead $(0.3 \%, n=323)$ were reported alive when landed. Entanglement in the branchlines and main line $(53.9 \%, \mathrm{n}=317)$ was more common than hooking $(43.5 \%)$, while $2.6 \%$ of turtles were both entangled and hooked. Assessment of the degree of injury caused by hooking was only possible for a subsample ( $\mathrm{n}=51$ ), in which turtles were categorized as severely injured $(41.2 \%, \mathrm{n}=51)$ or lightly injured $(58.8 \%)$. During the sampled trips we did not observe the sacrifice of any loggerhead for human use, possibly due to the observer's presence on board.

The location of bycatch loggerheads ranged from ca. 46.5 to $637.1 \mathrm{~km}$ (mean \pm SD: $155.7 \pm 4.95 \mathrm{~km}, \mathrm{n}=299$ turtle locations) from the coast, between latitudes 13 and $22^{\circ} \mathrm{S}$ (Fig. 1). From turtles with information on depth of capture, only 1 individual was captured in the neritic zone (water depth $=125 \mathrm{~m}$ ), while the remaining turtles $(99.67 \%, \mathrm{n}=298)$ were caught in oceanic waters (mean \pm SD depth: $4470.7 \pm 86.1 \mathrm{~m}$ ).

\section{Size class analysis}

Of the 323 loggerhead turtles caught in the present study, we obtained complete morphometric data from 307 individuals. The mean $( \pm \mathrm{SD}) \mathrm{CCL}$ of all captured loggerheads was $57.2 \pm 9.18 \mathrm{~cm}$ (range: 35.9 to $86.3 \mathrm{~cm}, \mathrm{n}=307)$. CCL was highly correlated with $\mathrm{CCW}$ (regression, CCL $=2.393+0.998 \times \mathrm{CCW}, \mathrm{r}^{2}=$ $0.89, \mathrm{p}<0.0001$ ), and therefore only CCL was examined for descriptive and comparative analyses (Fig. 2).

Using our classification criteria, we found that $91.5 \%$ of the loggerheads were juveniles, $8.1 \%$ were subadults, and only $0.3 \%$ (1 individual) was a possible adult (Fig. 2). Within the individuals classified as juveniles, the majority $(67.7 \%)$ corresponded to large juveniles between 50 and 70 CCL (Fig. 2).

\section{DISCUSSION}

The present study highlights how preliminary studies aimed at describing bycatch also facilitate studies of the demography of endangered marine fauna; a viable technique when other mechanisms are unavailable for data collection. This is particularly true for elusive species such as sea turtles that spend the majority of their lives in open ocean areas that are distant from research facilities and difficult to access by other means. We acknowledge the inherent bias in this approach, since vessels target specific areas and 'sampling' is selective, as collection is affected by gear type

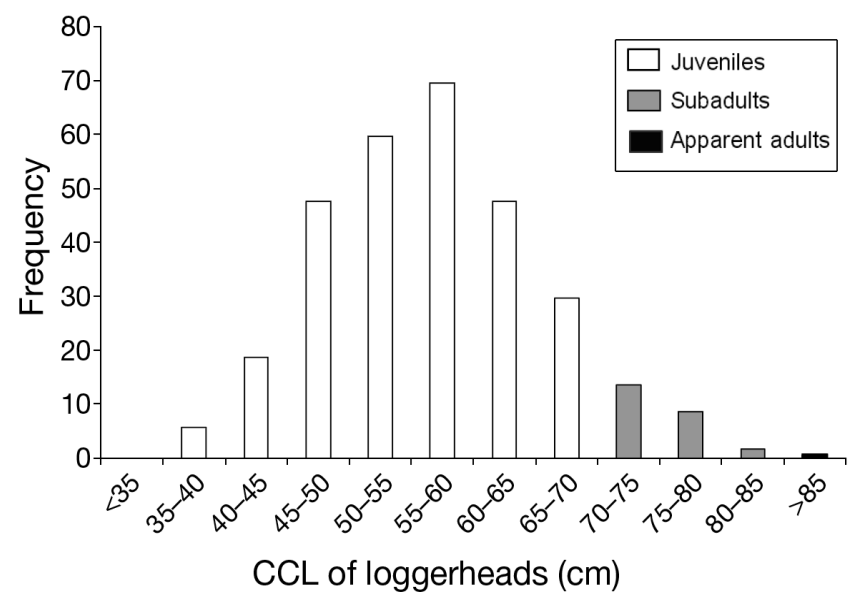

Fig. 2. Caretta caretta. Curved carapace length (CCL) distribution of loggerhead turtles incidentally caught in Peru $(\mathrm{n}=$ 307 ), showing the cut offs for every $5 \mathrm{~cm}$ of $\mathrm{CCL}$, between the 3 size classes $(n=307)$ : juveniles $(<70 \mathrm{~cm})$, subadults $(70$ to $85 \mathrm{~cm})$, and apparent adults $(>85 \mathrm{~cm})$. Categories are based upon CCL and not internal analysis of gonads (as in Heppell et al. 1996). Size classes were adopted from values from figures for CCL and maturity stage class presented in Limpus \& Limpus (2003b) 
and configuration as well as by fishing effort. However, in the absence of other fisheries-independent approaches available for studying threatened and endangered species at sea off Peru, we suggest that the collection of such data is essential for developing effective conservation programs, regardless of the potential biases. Moreover, data obtained from bycatch turtles have provided substantial information for population modeling, helping to determine key demographic and life-history components that have been vital for the development of related management policies and conservation measures for other sea turtle populations (Crouse et al. 1987, Crowder et al. 1994, Heppell et al. 1996, Chaloupka \& Limpus 2001).

Using our classification criteria, we obtained only 1 Caretta caretta individual categorized as adult. Considering information presented in Limpus \& Limpus (2003b), describing $80 \mathrm{~cm}$ CCL as the minimum breeding size documented for loggerheads in eastern Australia and given the variability in the relationship between size and maturity status, this apparent adult may also have been a large subadult. However, the absence of adults does not suggest that this fishery has an insignificant impact on southern Pacific loggerheads. Stage-based models of loggerhead turtles in the North Atlantic indicated that reduced survival rates of individuals ranging from 58.1 to $80 \mathrm{~cm}$ straight carapace length, which matches the size distribution recorded in our dataset, seriously impaired the survival or recovery of the population (Crouse et al. 1987). Heppell et al. (1996) determined similar results in a model for the eastern Australian loggerhead population.

Chaloupka (2003) modeled competing risk factors for the western South Pacific loggerhead stock across each life stage, concluding that declines in the population were probably due to chronic adult recruitment failures. Given the number of years sea turtles take to reach maturity, high and prolonged mortality of large juveniles may lead to similar recruitment failure and thus threaten population viability.

Known threats to the eastern Australian loggerhead population include fox predation on eggs, fishery bycatch by trawl, gillnet and crab trap fisheries on internesting and foraging turtles, boat strikes, and ingestion of synthetic debris (Limpus \& Reimer 1994, Poiner \& Harris 1996, Chaloupka 2003, Limpus \& Limpus 2003a). Using stochastic modeling, Chaloupka (2003) also showed how only 3 threats or competing risk factors (egg predation by foxes, bycatch of immature and adult turtles in coastal trawlers, and bycatch of oceanic juveniles in distant water longliners), stock viability would be negatively impacted. During the present study we reported that most loggerheads were released alive $(99.7 \%)$. Although a low direct mortality rate was observed $(0.32 \%)$, the high incidence of severely hooked and injured turtles (41.2\%) and evidence of post-hooking mortality (Chaloupka et al. 2004, Sasso \& Epperly 2007), combined with the large number of fishing trips, suggest that artisanal fisheries operating in coastal waters of Peru are a major threat to juvenile loggerheads at foraging grounds in the southeastern Pacific.

Ontogenic habitat shifts were first described as 'developmental migrations' by Carr (1987) and have been shown for a number of sea turtle populations (Carr et al. 1978, Bolten et al. 1998, Lahanas et al. 1998). For example, loggerheads in waters of the eastern North Pacific near Baja California, Mexico, are exclusively immature-sized turtles (Seminoff et al. 2004, Koch et al. 2006, Peckham et al. 2007), while those in the western North Pacific are largely adults. Telemetry and tagging studies suggest that loggerheads from foraging areas in the central and northeastern Pacific eventually migrate westward to Japan (Resendiz et al. 1998, Nichols et al. 2000) and remain in the western Pacific for the remainder of their lives in breeding and foraging areas around the Japanese rookeries (Sakamoto et al. 1997, Hatase et al. 2002).

Size at recruitment to coastal neritic foraging areas in eastern Australia from oceanic juvenile life stages ranges from 66.7 to $93.9 \mathrm{~cm}$ CCL (mean $=78.62 \mathrm{~cm}$ CCL) (Limpus \& Limpus 2003b). Therefore, most loggerheads from the present study were smaller than these neritic-stage juveniles and subadult recruits from eastern Australia. The preponderance of immature age classes in Peruvian waters, coupled with the absence of loggerheads between 4 and $\sim 70 \mathrm{~cm}$ CCL in eastern Australian waters (Limpus \& Limpus 2003b), suggests that southern Pacific loggerheads also make developmental movements, most likely in Australia and New Caledonia (P. H. Dutton et al. unpubl. data), to juvenile foraging habitat in the eastern Pacific, and back to adult foraging and nesting habitats in the western Pacific. The absence of adult size classes in the southeastern Pacific further suggests that breeders do not re-migrate to these foraging habitats.

Many of the loggerhead capture locations considered in the present study were in waters off northern Chile (Fig. 1), further highlighting the trans-boundary distribution of this species in the southeastern Pacific. Donoso et al. (2000) and Donoso \& Dutton (2006) reported loggerheads in Chilean waters as bycatch in the Chilean commercial high seas longline fisheries for swordfish. The potential impacts of Chilean artisanal coastal fisheries on loggerhead turtles are currently being investigated (M. Donoso pers. comm.).

The paucity of data available on the aquatic life stages of sea turtles can be addressed, and valuable biological information obtained, in part through the use of fishing vessels (including artisanal vessels) as research platforms and the implementation of onboard 
observer programs with appropriate research methods. Also, the use of onboard observers has the potential added benefit of encouraging the participation of the main stakeholders (fishermen) to become actively involved in research and conservation programs. We recommend the use of similar programs in the region and globally to help describe the demographic and habitat use characteristics of protected marine species.

Acknowledgements. We kindly acknowledge the fishermen and field observers for their generous collaboration. Fishermen Miguel Cuentas, Francisco Bernedo 'Chaval', Mateo Mamani, German Vela, Rosa Jimenez, Anibal Jimenez, Maria Valencia, Miguel Lopez, Lizandro Cuentas, Alex Bernaola, Miluska Jimenez, and Cesar Parra provided unique support to this study project. The vessels 'Milagritos', 'Mi Osquitar', 'Emmanuel', 'San Miguel I y II', 'Lucio I y II', 'Juan de Dios', 'Isurus', 'Maria Isabel', and 'Mi Fortaleza' were used. Pro Delphinus staff biologists and veterinarians M. Pajuelo, C. Caceres, P. Melly, and D. Vega provided great support in the field and data work. The manuscript was improved as a result of the input of 2 anonymous reviewers, Rebecca Lewison, and Brendan Godley. Funding was provided by the NOAA-Fisheries Southwest Fisheries Science Center, the National Fish and Wildlife Foundation, Columbus Zoo, Idea Wild, Cleveland Zoo, and the International Fund for Animal Welfare. The Instituto Nacional de Recursos Naturales INRENA provided the permits for research and sampling Nos. 015-2002INRENA- J-DGFFS-DCB, 070-2003-INRENA-IFFS-DCB, 0682004-INRENA-IFFS-DCB, and 002-2006-INRENA-IFFS-DCB. J.A.S. and J.C.M. were supported by the University of Exeter, and J.C.M. also received an ORSAS award.

\section{LITERATURE CITED}

Alfaro Shigueto J, Dutton PH, Mangel J, Vega D (2004) First confirmed occurrence of loggerhead turtles Caretta caretta in Peru. Mar Turtle Newsl 103:7-11

Alfaro Shigueto J, Dutton PH, Van Bressem MF, Mangel J (2007) Interactions between leatherback turtles and Peruvian artisanal fisheries. Chelonian Conserv Biol 6:129-134

Bal G, Breheret N, Vanleevwe H (2007) An update on sea turtle conservation activities in the Republic of Congo. Mar Turtle Newsl 116:9-10

Bertrand A, Segura M, Gutiérrez M, Vásquez L (2004) From small-scale habitat loopholes to decadal cycles: a habitatbased hypothesis explaining fluctuation in pelagic fish populations off Peru. Fish Fish 5:296-316

Bolten AB (1999) Techniques for measuring sea turtles. In: Eckert KL, Bjorndal KA, Abreu-Grobois AF, Donelly M (eds) Research and management techniques for the conservation of sea turtles. Publication No. 4, IUCN/SSC Marine Turtle Specialist Group, Blanchard, PA, p 126-132

Bolten AB, Bjorndal KA, Martins HR, Delinger T, Biscoitto MJ, Encalada SE, Bowen BW (1998) Transatlantic developmental migrations of loggerhead sea turtles demonstrated by mtDNA sequence analysis. Ecol Appl 8:1-7

Bowen BW (1995) Tracking marine turtles with genetic markers. Bioscience 45:528-534

Carr A (1987) New perspectives on the pelagic stage of sea turtle development. Conserv Biol 1:103-121

Carr AF, Carr MH, Meylan AB (1978) The ecology and migrations of sea turtles, Vol 7. The west Caribbean green turtle colony. Bull Am Mus Nat Hist 162:1-46
Casale P, Cattarino L, Freggi D, Rocco M, Argano R (2007) Incidental catch of marine turtles by Italian trawlers and longliners in the central Mediterranean. Aquat Conserv Mar Freshw Ecosyst 17:686-701

Chaloupka M (2003) Stochastic simulation modeling of loggerhead population dynamics given exposure to competing mortality risks in the western South Pacific. In: Bolten $\mathrm{AB}$, Witherington BE (eds) Loggerhead sea turtles. Smithsonian Books, Washington, DC, p 275-294

Chaloupka M, Limpus CJ (2001) Trends in the abundance of sea turtles resident in southern Great Barrier Reef waters. Biol Conserv 102:235-249

Chaloupka M, Parker D, Balazs G (2004) Modelling post release mortality of loggerhead sea turtles exposed to the Hawaii-based pelagic longline fishery. Mar Ecol Prog Ser 280:285-293

Compagno L, Dando M, Fowler S (2005) Sharks of the world. Princeton University Press, Princeton, NJ

Crouse DT, Crowder LB, Caswell H (1987) A stage based population model for loggerhead sea turtles and implications for conservation. Ecology 68:1412-1423

Crowder LB, Crouse DT, Heppell SS, Martin TH (1994) Predicting the impact of turtle excluder devices on loggerhead sea turtle population. Ecol Appl 4:437-445

Donoso M, Dutton PH (2006) Distribution and stock origin of sea turtles caught incidentally in the Chilean longline fishery for swordfish, 2001-2004. In: Frick M, Panagopoulou $\mathrm{A}$, Reese AF, Williams $\mathrm{K}$ (compilers) Book of Abstracts. 26th annual symposium on sea turtle biology and conservation, Athens

Donoso M, Dutton PH, Serra R, Brito-Montero JL (2000) Sea turtles found in waters off Chile. In: Kalb HJ, Wibbels T (eds) Proceedings of the 19th annual symposium on sea turtle biology and conservation. NOAA Tech Memo NMFS-SEFSC 443:218-219

Dossa JS, Sinsin BA, Mensah GA (2007) Conflicts and social dilemmas associated with the incidental capture of marine turtles by artisanal fishers in Benin. Mar Turtle Newsl 116:10-12

Dutton PH, Squires D (2008) Reconciling biodiversity with fishing: a holistic strategy for Pacific sea turtle recovery. Ocean Dev Int Law 39:200-222

El Peruano Ministerio de la Produccion (2001) Ley general de pesca. Reglamento de la ley general de pesca. Decreto Supremo No. 012-2001-PE, El Peruano Ministerio de la Produccion, Lima, p 199905-199921

Escudero L (1997) Encuesta estructural de la pesqueria artesanal del litoral peruano. Informe Progresivo No. 59, Instituto del Mar del Peru, La Punta Callao

Estrella C (2007) Resultados generales de la segunda encuesta estructural de la pesqueria artesanal en el litoral peruana (ENEPA 2004-2005). Informe del Instituto del Mar del Peru IMARPE. Available at: www. imarpe.gob.pe

Estrella C, Guevara-Carrasco R, Palacios J, Avila W, Medina A (1999) Informe estadístico de los recursos hidrobiológicos de la pesca artesanal por especies, artes, meses y caletas durante el primer semestre de 1999. No. 148, Instituto del Mar del Perú, La Punta Callao

Estrella C, Guevara-Carrasco R, Palacios J, Avila W, Medina A (2000) Informe estadístico de los recursos hidrobiológicos de la pesca artesanal por especies, artes, meses y caletas durante el segundo semestre de 1999. No. 151, Instituto del Mar del Perú, La Punta Callao

Fiedler F, Philbrick V, Chavez F (1991) Oceanic upwelling and productivity in the eastern tropical Pacific. Limnol Oceanogr 36:1834-1850 
Gallo BMG, Macedo S, Giffoni BDB, Becker JH, Barata PCR (2006) Sea turtle conservation in Ubatuba, southeastern Brazil, a feeding area with incidental capture in coastal fisheries. Chelonian Conserv Biol 5:93-101

Harrison P (1983) Seabirds an identification guide. Houghton Mifflin Company, Boston, MA

Hatase H, Takai N, Matsuzawa W, Sakamoto W and others (2002) Size-related differences in feeding habitat use of adult female loggerhead turtles Caretta caretta around Japan determined by stable isotope analyses and satellite telemetry. Mar Ecol Prog Ser 233:273-281

Hatziolos M, de Haan C (2006) An opportunity for a different Peru: prosperous, equitable and governable. In: Giugale MM, Fretes-Cibils V, Newman JL (eds) Sustainable fisheries through improved management and policies. World Bank Press

Heppell SS, Limpus CJ, Crouse DT, Frazer NB, Crowder LB (1996) Population model analysis for the loggerhead sea turtles, Caretta caretta, in Queensland. Wildl Res 23: $143-159$

IUCN (International Union for Conservation of Nature and Natural Resources) (2007) IUCN Redlist of threatened species. The Conservation Union, Cambridge. Available at: www.redlist.org

Jefferson TA, Leatherwood S, Webber MA (1993) FAO species identification guide, marine mammals of the world. United Nations Environment Programme, Food and Agriculture Organization of the United Nations, Rome

Kamezaki N, Matsuzawa Y, Abe O, Asaka H and others (2003) Loggerhead turtles nesting in Japan. In: Bolten AB, Witherington BE (eds) Loggerhead sea turtles. Smithsonian Books, Washington, DC, p 210-217

Kelez S, Velez-Suazo X, Manrique C (2003) New evidence on the loggerhead sea turtle Caretta caretta (Linneaus, 1758) in Peru. Ecol Appl 2:141-142

Koch V, Nichols WJ, Peckham H, de la Toba V (2006) Estimates of sea turtle mortality from poaching and bycatch in Bahía Magdalena, Baja California Sur, Mexico. Biol Conserv 128:327-334

Lahanas PN, Bjorndal KA, Bolten AB, Encalada SE, Miyamoto MM, Valverde RA, Bowen BW (1998) Genetic composition of a green turtle (Chelonia mydas) feeding ground population: evidence for multiple origins. Mar Biol 130:345-352

Lewison RL, Crowder LB (2007) Putting longline bycatch of sea turtles into perspective. Conserv Biol 21:79-86

Lewison RL, Freeman S, Crowder LB (2004) Quantifying the effects of fisheries on threatened species: the impact of pelagic longlines on loggerhead and leatherback sea turtles. Ecol Lett 7:221-231

Limpus CJ, Limpus DJ (2003a) Loggerhead turtles in the equatorial and southern Pacific Ocean. In: Bolten $A B$, Witherington BE (eds) Loggerhead sea turtles. Smithsonian Books, Washington, DC, p 199-209

Limpus CJ, Limpus DJ (2003b) Biology of the loggerhead turtle in western South Pacific Ocean foraging areas. In: Bolten AB, Witherington BE (eds) Loggerhead sea turtles. Smithsonian Books, Washington, DC, p 93-113

Limpus CJ, Reimer D (1994) The loggerhead turtle Caretta caretta in Queensland: a population decline. In: James R (ed) Proceedings of the Australian marine turtle conservation workshop. Australian Nature Conservation Agency, Canberra, p 39-59

Lum LL (2006) Assessment of incidental sea turtle catch in the artisanal gillnet fishery in Trinidad and Tobago, West Indies. Appl Herpetol 3:357-368
Nichols J, Resendiz A, Seminoff J, Resendiz B (2000) Transpacific migration of loggerhead turtle monitored by satellite telemetry. Bull Mar Sci 67:937-947

Onley D, Bartle S (1999) Identificación de aves marinas de los Oceános del Sur. Te Papa Press, Wellington

Peckham SH, Maldonado Diaz D, Walli A, Ruiz G, Crowder LB, Nichols J (2007) Small-scale fisheries bycatch jeopardizes endangered Pacific loggerhead turtles. PLoS ONE 2:e1041

Poiner IR, Harris ANM (1996) The incidental capture, direct mortality and delayed mortality of turtles in Australia's northern prawn fishery. Mar Biol 125:813-825

Polovina JJ, Kovayashi DR, Parker DM, Seki MP, Balazs GH (2000) Turtles on the edge: movement of loggerhead turtles (Caretta caretta) along oceanic fronts, spanning longline fishing grounds in the central North Pacific, 19971998. Fish Oceanogr 9:71-82

Polovina JJ, Balazs GH, Howell EA, Parker DM, Seki MP, Dutton PH (2004) Forage and migration habitat of loggerhead (Caretta caretta) and olive ridley (Lepidochelys olivacea) in the central North Pacific Ocean. Fish Oceanogr $13: 36-51$

Polovina J, Uchida I, Balazs G, Howell EA, Parker D, Dutton P (2006) The Kuroshio Extension Bifurcation Region: a pelagic hotspot for juvenile loggerhead sea turtles. DeepSea Res II 53:326-339

Pritchard PCH, Mortimer J (1999) Taxonomy, external morphology, and species identification. In: Eckert KL, Bjorndal KA, Abreu-Grobois FA, Donelly M (eds) Research and management techniques for the conservation of sea turtles. Publication No. 4, IUCN/SSC Marine Turtle Specialist Group, Blanchard, PA, p 21-38

Pupo MM, Soto JMR, Hanazaki N (2006) Incidental catch of marine turtles by the artisanal fisheries on Santa Catarina Island, SC, Brazil. Biotemas 19:63-72

> Read A (2007) Do circle hooks reduce the mortality of sea turtles in pelagic longlines? A review of recent experiments. Biol Conserv 135:155-169

Resendiz A, Resendiz B, Nichols WJ, Seminoff JA, Kamezaki N (1998) First confirmed east-west transpacific movement of a loggerhead sea turtle, Caretta caretta, released in Baja California Mexico. Pac Sci 52:151-153

Sakamoto W, Bando T, Arai N, Baba N (1997) Migration paths of adult female and male loggerhead turtles, Caretta caretta, determined through satellite telemetry. Fish Sci 63:547-552

Sasso CR, Epperly SP (2007) Survival of pelagic juvenile loggerhead turtles in the open ocean. J Wildl Manag 71: 1830-1835

Seminoff JA, Resendiz A, Resendiz B, Nichols WJ (2004) Occurrence of loggerhead sea turtles (Caretta caretta) in Gulf of California, Mexico: evidence of life-history variation in the Pacific Ocean. Herpetol Rev 35:24-27

Uchida I, Nishiwaki M (1992) Sea turtles in the waters adjacent to Japan. In: Bjorndal KA (ed) Biology and conservation of sea turtles. Smithsonian Institution Press, Washington, DC, p 317-319

Wetherall JA, Balazs GH, Tokunaga RA, Yong MYY (1993) Bycatch of marine turtles in North Pacific high seas driftnet fishery and impacts on stock. In: Ito J (ed) International North Pacific Fisheries Commission: symposium on biology, distribution and stock assessment of species caught in the high seas driftnet fisheries in the North Pacific Ocean, Vol 53. Bull INPFC, Honolulu, HI, p 519-538 